УДК 94: 504(327) «1970»

\title{
МІЖНАРОДНИЙ ВЕКТОР ЕКОЛОГІЧНОЇ ПОЛІТИКИ АВСТРАЛІЇ: 1970-ТІ РОКИ
}

\section{Перга Тетяна Юріївна}

кандидат історичних наук, старший науковий співробітник, ДУ «Інститут всесвітньої історії НАН України», м. Київ, Україна

Надіслано: 07.03.2021 Рецензовано: 18.03.2021 Прийнято: 05.04.2021

ORCID: 0000-0002-8725-3451

pergatatiana@gmail.com

Метою дослідження $є$ виявлення особливостей етапу становлення зовнішнього вектора екологічної політики Австралії, який віднесено до 1970-х рр. Дослідження проведено на основі аналізу документів Парламенту Австралії, Департаменту зовнішніх відносин і торгівлі та Міністерства води, сільського господарства i навколишнього середовища. У результаті дослідження встановлено, що до поч. 1970-х рр. в Австралії було прийнято низку перших міжнародних угод, які сформували підгрунтя для подальшого розвитку багатостороннього екологічного співробітництва. У цей період були відпрацьовані різні механізми і моделі багатостороннього співробітництва. Розкрита роль Конференції ООН з Навколишнього середовища, яка відбулася у Стокгольмі в 1972 р., у розвитку міжнародного екологічного співробітництва нового рівня. Доведено, що на цей момент в Австралії загострилася низка екологічних проблем, що обумовило потребу країни у широкому обміні інформацією з іншими країнами світу щодо їх подолання і більш тісного об'єднання зусиль у боротьбі з ними. Саме в цей час в Австралії і на рівні федерації і на рівні штатів були створені державні установи, відповідальні за впровадження екологічної політики, що сприяло координації внутрішнього і зовнішнього вектора природоохоронної діяльності. Зроблено висновок, що саме після цієї конференції, у 1970-х рр., розпочався період становлення міжнародного вектора екологічної політики Австралії, адже ця діяльність грунтувалася на нових засадах і принципах і включила нові напрями. Продемонстровано її особливість. Наголошено на великій ролі, яку приділяє Парламент Австралії виконанню міжнародних угод.

(С)ерга Т. Ю., 2021 


\section{Міжнародні відносини: теоретико-практичні аспекти \\ Випуск 7 (2021) \\ ISSN (print) 2616-745X; ISSN (online) 2616-7794}

Ключові слова: Австралія; міжнародні відносини; екологічне співробітництво; зовнішня політика; екологічна політика; Конференція ООН з навколишнього середовища 1972 р.

\section{Вступ}

Останніми роками в Австралії помітно загострилися екологічні проблеми, серед яких надзвичайно швидка деградація Великого бар'єрного рифу, почастішання та збільшення інтенсивності лісових пожеж, спричинених зміною клімату. Водночас екологічній політиці країни притаманна амбівалентність: 3 одного боку, Австралія розширює міжнародне співробітництво з їхнього подолання і впроваджує низку еко-орієнтованих ініціатив у внутрішній політиці; а 3 іншого, - продовжує розвивати ті галузі економіки, які роблять значний внесок у забруднення довкілля та формування парникового ефекту, що спричиняє зміну клімату (насамперед, мова йде про вуглевидобування). Це актуалізує дослідження різних аспектів екологічної політики країни, зокрема їі зовнішнього вектора, адже в умовах глобалізації зростає роль міжнародного співробітництва у подоланні багатьох проблем світового характеру.

Австралія має низку здобутків у царині міжнародного екологічного співробітництва. Значний практичний інтерес для України має вивчення періоду становлення міжнародного вектора екологічної політики Австралії. Критичний аналіз їі досвіду може сприяти виробленню рекомендацій для України щодо розвитку багатосторонніх екологічних відносин в царині захисту довкілля.

\section{Аналіз останніх досліджень і публікацій}

У закордонній, зокрема австралійській історіографії, різні аспекти екологічної політики країни займають важливе місце в широкому науковому дискурсі. Велика група наукових праць присвячена адаптації австралійського законодавства до міжнародного екологічного права та його впровадження в політику різних урядів (К. Холі, Г. Хоуз, Е. Джукіч, М. А. Янг, П. Барнет та ін.), що свідчить про важливість цього напряму урядової діяльності. Протягом останніх десятиліть помітно зросла чисельність розвідок, які вивчають проблеми та перспективи участі Австралії у міжнародному співробітництві щодо зменшення негативних наслідків зміни клімату (Е.Фіні, М.Бісон, М. Макдональд, Л. Хед та ін.); збереження біорізноманіття (А.Р.Парті, Д. Фройденбергер, Дж. Стол та ін.); захисту морської флори і фауни (Є. Чіркоп, Р. К. Крейг, Є Юньен та ін.); охорони китів (М. Бейдер, Д. К. Антон, Л. М. Мюллер, Дж. Моссоп, В. Піротта та ін.), що демонструє зростаючу зацікавленість країни у розширенні секторальної багатосторонньої співпраці. 


\section{Формулювання цілей статті}

На противагу, в українській історичній науці і політичних студіях тема екологічної політики Австралії, зокрема участі країни в міжнародному співробітництві із захисту довкілля, вивчена недостатньо. Джерельною базою нашого дослідження є офіційні документи державних установ: Парламенту Австралії, Департаменту зовнішніх відносин і торгівлі та Міністерства води, сільського господарства i навколишнього середовища. Методологія дослідження базується на аналізі низки документів вказаних установ.

У цій статті ми маємо намір розглянути передумови формування міжнародного вектора екологічної політики Австралії і його розвиток у 1970-х рр. Саме цей період, на наш погляд, варто вважати етапом його становлення, адже Конференція з навколишнього середовища, яка відбулася у Стокгольмі в 1972 р., стала епохальною подією в міжнародному екологічному співробітництві, піднявши його на новий рівень, заклавши головні засади, принципи i напрями взаємодії держав щодо припинення деградації навколишнього середовища.

\section{Виклад основного матеріалу дослідження}

Географічне положення (Австралія є острівною державою) обумовило особливий інтерес країни до охорони приберегової і морської флори і фауни, тому перші міжнародні угоди вона уклала саме в цій царині. Так, у 1913 р. Австралія приєдналася до підписаної 7 липня 1911 р. у Вашингтоні Конвенції про збереження та захист морських котиків (ї̈ сторонами були США, Великобританія, Японія та Росія). Це був перший міжнародний договір, присвячений питанням збереження дикої природи. У квітні 1922 р. Австралія стала підписантом ще однієї міжнародної угоди - Про організацію кампанії проти саранчі, яку 31 жовтня 1920 р. у Римі уклали Аргентинська Республіка, Болгарія, Куба, Франція, Французька Західна Африка, Алжир, Індо-Китай, Мадагаскар, Марокко (Французька зона), Регентство Туніс, Угорщина, Італія, Еритрея, Італія, Сомаліленд, Триполітанія, Кіренаїка, Мексика, Сербія, Хорватія, Словенія, Уругвай.

Однак найбільший інтерес для Австралії у пер. пол. ХХ ст. мало регулювання китобійного промислу. У 1937 р. вона підписала першу Міжнародну угоду про регулювання китобійного промислу, у1946 р. - другу. у наступні десятиліття до них було підписано понад сорок додатків, які Австралія підписала (The Australian Treaties Database, 2021). Інтерес країни до китів обумовлений тим, що з часу виникнення промислового китобійного промислу XVII ст. в усьому світі було вбито понад мільйон китів. Цей масштаб

(С)ерга Т. Ю., 2021 


\section{Міжнародні відносини: теоретико-практичні аспекти \\ Випуск 7 (2021) \\ ISSN (print) 2616-745X; ISSN (online) 2616-7794}

китобійного промислу сильно вплинув на більшість популяцій китів та суттєво змінив їх екологічну роль у широкому морському середовищі. У результаті багато видів китів опинилися під загрозою зникнення. Нині їх можна віднести до категорії «вразливі», «зникаючі» або «критично зникаючі» (Marine publications and resources, 2021). Проблемі захисту морських видів була присвячена і підписана в 1949 р. Угода про створення Ради з риболовства в Індо-Тихоокеанському регіоні, яка тепер відома як Азіатсько-Тихоокеанська комісія з риболовлі (The Australian Treaties Database, 2021).

Іншими угодами, до яких долучилася Австралія до поч. 1950-196-х рр., $€$ такі: Міжнародна конвенція про захист рослин (1952), Міжнародна конвенція про запобігання забрудненню моря нафтою (1954) з поправками, включаючи поправки щодо Великого бар'єрного рифу (1971), Угода про захист рослин в Азіатсько-Тихоокеанського регіоні (1956), Паризька конвенція про відповідальність третіх сторін у галузі ядерної енергетики (1960), Угода між урядами Австралії, Аргентини, Бельгії, Чилі, Французької Республіки, Японії, Нової Зеландії, Норвегії, Південно-Африканського Союзу, Союзу Радянських Соціалістичних Республік, Сполученого Королівства Великобританії та Північної Ірландії та Сполучених Штатів Штати Америки щодо мирного використання Антарктиди (1961), Віденська конвенція про цивільну відповідальність за ядерну шкоду (під егідою МАГАТЕ) (1963), Міжнародна конвенція про створення Міжнародного фонду компенсації за збитки, спричинені забрудненням нафти, від 18 грудня 1971 року (1971), Конференція про створення Міжнародного фонду компенсації збитків забрудненням нафти (1971). Також у 1956 р. Австралія приєдналася до діяльності Міжнародного агентства з атомної енергії (The Australian Treaties Database, 2021).

У пер. пол. XX ст. перші екологічні проблеми лише почали формуватися, тому вказані угоди окреслили перші напрями охорони деяких природних ресурсів. Однак участь у них створила підгрунтя для переходу Австралії на поч. 1970-х рр. до екологічного співробітництва нового рівня - на основі нових принципів і підходів, розроблених світовою спільнотою. Досвід природоохоронної співпраці пер. пол. XX ст. сприяв напрацюванню різних моделей і механізмів взаємодії, а також формуванню зовнішньополітичних екологічних інтересів Австралії. Характерною рисою цього періоду є укладання угод, що мали поставити під контроль вплив розвитку атомної енергетики на довкілля, що було обумовлено випробуваннями атомної зброї і початком використання атомної енергії у мирних цілях низкою країн. Також було зроблено перші кроки з охорони флори і фауни, боротьби із забрудненням морів. 
Загострення екологічних проблем у багатьох країнах світу наприкінці 1960-х рр. - поч. 1970-х рр., транскордонний характер забруднення повітря, водного простору, зокрема Світового океану, спонукали країни світу до активізації зусиль з природоохоронного співробітництва. Із ініціативи Швеції на 23-й сесії Генеральної Асамблеї ООН у 1968 р. було вирішено провести у 1972 p. Конференцію ООН з навколишнього середовища, яка мала сфокусувати увагу на вирішенні пріоритетних проблем, пов'язаних з довкіллям і сприяти координації зусиль країн у цій царині.

Австралія одна з перших підтримала цю ініціативу і взяла активну участь у підготовці конференції. Хоча вона на увійшла до підготовчого комітету конференції, представники країни взяли участь у його діяльності в якості спостерігачів. Також австралійські експерти постійно відвідували зустрічі міжурядових робочих груп. Під час загальних дебатів у Генеральній Асамблеї ООН 22 вересня 1969 р. міністр закордонних справ Австралії присвятив велику частину своєї промови майбутній конференції, виклавши погляди уряду на досягнення Організації Об'єднаних Націй в охороні довкілля і у підготовці цієї зустрічі.

На поч. 1971 р. Австралія підготувала національну доповідь і пропозиції щодо 14 тем для обговорень, кілька 3 яких було взято Секретаріатом Конференції для включення в порядок денний заходу. На запрошення Секретаріату Національна комісія з розвитку капіталу провела дослідження на тему «Розвиток нових міст у Канберрі».

Австралійську делегацію на Конференції очолив П. Хоусон, Міністр навколишнього середовища, аборигенів та мистецтв Співдружності. До ii складу увійшли також Міністр охорони навколишнього середовища Нового Південного Уельсу Дж. Біл, міністр з питань розвитку штату Вікторія В. О. Дікі,представники екологічних установ від кожного штату і вищі посадовці країни.

У вітальному слові 3 нагоди відкриття конференції голова австралійської делегації П.Хоусон сказав: «Екологічні проблеми Австралії не такі гострі, як у деяких інших країнах. У нас немає тиску населення на ресурси, які сприяли появі екологічних проблем у деяких країнах. Наша географічна ізоляція як острівного континенту робить нас менш уразливим до транскордонного забруднення. Але у нас $\epsilon$ свої екологічні завдання та проблеми. Вони не лише отримують пріоритет від австралійської влади, але вони, на мою думку, мають характер, який стосується багатьох інших країн. Австралія $є$ індустріальною країною, що швидко розвивається, а також сильно

(СПерга Т. Ю., 2021 


\section{Міжнародні відносини: теоретико-практичні аспекти \\ Випуск 7 (2021) \\ ISSN (print) 2616-745X; ISSN (online) 2616-7794}

урбанізованою - 85 \% нашого населення проживає в містах. Наш подальший розвиток потребує гарантій уникнення екологічних проблем, 3 якими нині стикається багато розвинених країн світу, хоча в деяких питаннях, принаймні певною мірою, ми вже в гіршому становищі, ніж хотіли б. Але ми також велика сільськогосподарська, скотарська та гірничодобувна країна. Екологічні проблеми не обмежуються лише високорозвиненими країнами і не $\epsilon$ продуктом лише промислової революції.

Забезпечення безпечного водопостачання та водовідведення у зростаючих містах і селах $\epsilon$ проблемами для всіх країн. Нерозумне землеробство може звести родючі райони до пустелі - приклади, що існували понад тисячу років тому, доводять це... Багато країн, більш або менш розвинених, стикаються з проблемою ерозії грунтів. Австралія бореться з цими проблемами з певним успіхом вже 30 років.

Засолення грунту також є актуальною проблемою для багатьох країн, які не $\epsilon$ високоіндустріальними. Управління запасом хребта, розвиток тропічних пасовищ, контроль посушливих зон, захист нашої унікальної флори і фауни та збереження Великого Бар'єрного рифу - усе це питання, в яких Австралія виконала велику роботу, яка зацікавила інші країни і в якій ми виграли від співпраці та обміну думками з іншими. Австралія налаштована захищати довкілля».

Якраз напередодні конференції в Австралії, як і деяких європейських країнах, розпочалася інституалізація природоохоронної діяльності. У кожному 3 шести штатів країни були створені спеціалізовані агентства в цій галузі, а на рівні співдружності - Австралійська рада 3 питань навколишнього середовища, до складу якої увійшли їхні представники. П. Хоусон назвав цю модель екологічного управління кооперативним федералізмом. До речі, до складу австралійської делегації були включені міністри навколишнього середовища двох штатів з найбільшим населенням - Нового Південного Уельсу та Вікторії. Також в Австралії на поч. 1970-х рр. з'явилася Консультативна рада з питань землекористування, на яку покладалося завдання консультувати державні органи щодо екологічних міркувань, пов'язаних 3 майбутнім використанням будь-якої землі, що знаходиться під контролем уряду в Австралії. Це свідчить про те, що зовнішній вектор екологічної політики

Австралії розвивався не як окремі спорадичні заходи, а як цілеспрямована діяльність, що логічно продовжила розвиток внутрішньої екологічної політики на рівні штатів і співдружності. 
На думку голови австралійської делегації, багато екологічних проблем у світі виникли через недостатню обізнаність щодо наслідків людських дій для навколишнього середовища та відсутність знань про взаємодію різних систем. Він сказав: «Іноді ті, хто приймає рішення, не знають про існування вже наявних знань: в інших випадках дані $\epsilon$ неповними, а методи та теоретичні принципи та зв'язки ще не досліджені та не виявлені. Ми повинні боротися проти обох форм незнання. Однією з галузей, для якої нам потрібно більше знань, є вимірювання впливу нашої діяльності на навколишнє середовище. Ніхто серйозно не ставить під сумнів пропозицію про те, що слід уважно розглядати економічні наслідки будь-якого проєкту розвитку на національному чи міжнародному рівнях. Однак, без урахування повного впливу проекту на навколишнє середовище, економічні наслідки вимірюються не повністю. Набагато більше потрібно зробити як в теоретичній площині, так і в прикладній економіці, щоб дати змогу дізнатися про загальні витрати в найширшому розумінні, щоб ті, хто прийматиме рішення, мали змогу зважити на переваги та недоліки продовження певного курсу дії.

Багато витрат і вигод нематеріальні, непрямі та довгострокові... економістів слід заохочувати надавати більше допомоги, ніж ми маємо сьогодні. Я впевнений, що існує можливість для плідного міжнародного обміну в цій галузі». Він наголосив на важливості моніторингу стану навколишнього середовища на глобальній основі.«Австралія готова зіграти всю свою роль у такій програмі... Австралія, як континент, підтверджує свою особливу зацікавленість у будь-яких діях і програмах глобального характеру». Він закликав уникати апатії чи паніки. «До кожної пропозиції слід підходити по суті, пам'ятаючи, що поряд із нашою метою збереження людського середовища є метою підвищення рівня життя у всьому світі», - сказав П. Хаусон (United Nations Conference on the Human Environment: Report, 1972).

Австралія, нарівні з усіма 113 країнами - учасницями конференції підтримала і підписала документи, прийняті на Стокгольмській конференціїДекларацію Конференції Організації націй 3 проблем навколишнього середовища людини (United Nations Conference on the Human Environment: Declaration, 1972), в якій було викладено 26 принципів охорони довкілля, план дій з 109 пунктів, Програми ООН по довкіллю (ЮНЕП), Фонду довкілля (United Nations Conference on the Environment, 1972).

Ця конференція мала доленосне значення для подальшого розвитку та становлення глобальної екологічної політики, адже саме на Стокгольмській конференції вперше було визначено спільні цілі держав, головні принципи та

(СПерга Т. Ю., 2021 


\section{Міжнародні відносини: теоретико-практичні аспекти \\ Випуск 7 (2021) \\ ISSN (print) 2616-745X; ISSN (online) 2616-7794}

правові засади діяльності в природоохоронній сфері, а також закладено підвалини інституційної та фінансової архітектури глобального екологічного управління. Одним з найважливіших результатів конференції є Стокгольмська декларація 3 навколишнього середовища, яка закладає фундаментальні принципи розвитку людства з урахуванням впливу на довкілля. У наступні роки багато з них перетворились на головні орієнтири діяльності та лягли в основу широкої низки міжнародних документів, давши поштовх формуванню екологічного права (Perga, 2014, p. 40).

Після Стокгольмської конференції 3 навколишнього середовища міжнародне співробітництво щодо захисту довкілля (зокрема його різних сфер) помітно розширилося і поглибилося. Багато ідей, висловлених на конференції щодо співпраці всіх країн, великих і малих, на основі рівноправності, потреби єдиного i скоординованого підходу до планування свого розвитку, відповідальності держав за забезпечення того, щоб діяльність в рамках їх юрисдикції або контролю не завдавала шкоди навколишньому середовищу інших держав або районів за межами дії національної юрисдикції, відповідальності і компенсації жертвам за забруднення та за інші види шкоди, завдані в результаті діяльності в межах їх юрисдикції, або контролю за навколишнім середовищем в районах, що знаходяться за межами дії їх юрисдикції, оцінки впливу на довкілля та інші були покладені в основу нових міжнародних угод в царині захисту довкілля.

Документи, які підписала Австралія протягом 1970-х рр., відображають ці ідеї, а також головні екологічні проблеми, які турбували міжнародну спільноту в цей час - транскордонне забруднення атмосфери і водного простору, формування деградації флори і фауни. У цей період Австралія долучилася до таких міжнародних угод: Конвенція про запобігання забрудненню моря шляхом скидання з кораблів та літаків (1972), Угода про продовження дії Угоди про регіональну кооперацію з досліджень, розробок та підготовки кадрів, пов'язаної з ядерною наукою та технологіями, 1972 р. (1972), Угода між Австралією, Японією та Міжнародним агентством з атомної енергії (МАГАТЕ) про застосування гарантій Агентства стосовно цих урядів (Австралія, Японія) про співпрацю у мирних цілях використання атомної енергії від 21 лютого 1972 р. (1972), Міжнародна конвенція про запобігання забрудненню з кораблів (1973), Конвенція про охорону світової культурної та природної спадщини (1975), Міжнародна конвенція про торгівлю певними видами дикої природи (1976), Протокол до Конвенції 1979 р. Про трансграничне забруднення повітря важкими металами на великі відстані (1975), Угода про міжнародну енергетичну програму (1979), Конвенція про транскордонне забруднення атмосфери великими відстанями стійкими 
органічними забруднювачами (1979), Конвенція про роботу в рибному секторі, прийнята Конференцією на ії 96-й сесії Конвенція Південнотихоокеанського форуму про рибне господарство (1979) (The Australian Treaties Database, 2021). Особливістю екологічного співробітництва Австралії в цей період $є$ широка увага до проблем охорони морського простору від забруднення, рибальства, перевилову риби i спроба його врегулювати як на рівні регіону, так і глобальному. У цей час було підписано також багато протоколів до угод, підписаних у попередні десятиліття.

Маємо наголосити, що Парламент Австралії приділяв і приділяє велику увагу виконанню міжнародних зобов'язань країни. На це вказано на сайті Парламенту, у розділі «Повноваження співдружності щодо довкілля». Зокрема зазначено, що повноваження співдружності у цій царині проявляються у «можливості регулювати будь-які справи, що трапляються за межами Австралії, реалізовувати угоди, учасником яких є Австралія, шляхом прийняття відповідного законодавства та контролю за будь-якою справою, яка $\epsilon$ внутрішньою чи міжнародною, незалежно від будь-якої угоди». Комітет Сенату з питань навколишнього середовища, комунікацій, інформаційних технологій та мистецтв заявив, що співдружність повинна повною мірою та ефективно реалізовувати свої повноваження щодо ведення переговорів, реалізації та виконання своїх міжнародних екологічних зобов'язань (Implementing Australia's International Obligations, 2021).

\section{Висновки}

Таким чином, міжнародне співробітництво $€$ важливим вектором екологічної політики Австралії. Хоча воно почало формуватися ще на поч. XX ст., лише після Другої світової війни унаслідок появи перших ознак деградації окремих природних ресурсів деякі країни світу, включаючи Австралію, почали укладати багатосторонні угоди з охорони деяких видів природних ресурсів. Стокгольмська конференція з навколишнього середовища дала імпульс міжнародній співпраці в екологічній сфері, скоординувала і спрямувала зусилля держав на боротьбу з актуальними на той час екологічними проблемами. Тому саме 1970-ті рp. варто вважати періодом становлення міжнародного вектора екологічної політики Австралії. Перспективною подальших досліджень може стати вироблення рекомендацій для України на основі грунтовного аналізу досвіду Австралії.

(СПерга Т. Ю., 2021 


\section{References:}

1. 'Implementing Australia's International Obligations'. (2021). Parliament of Australia, [online].

Available

at: https://www.aph.gov.au/parliamentary_business/committees/senate/environment_ and_communications/completed_inquiries/1999-02/enviropowers/report/c04.

2. 'Marine publications and resources'. (2021). Australian Government, [online]. Available at: https://www.environment.gov.au/marine/publications\#species.

3. Perga, T. Yu. (2014). Global'naya ekologicheskaya politikai Ukrainy [Global environmental policy and Ukraine]. Nizhin: PP Lysenko.

4. 'The Australian Treaties Database'. (2021). Australian Government, [online] Available at :https://info.dfat.gov.au/Info/Treaties/Treaties.nsf/.

5. United Nations Conference on the Environment, 5-16 June 1972, Stockholm. The [online]. Available at https://www.un.org/en/conferences/environment/stockholm1972.

6. United Nations Conference on the Human Environment: Declaration, Stockholm, Sweden, June 5-16, 1972. The UN, [online]. Available at: https://www.un.org/ru/documents/decl_conv/declarations/declarathenv.shtml.

7. United Nations Conference on the Human Environment: Report A/CONF.48/14/REV.1. Stockholm, Sweden, June 5-16, 1972. The UN, [online]. Available at: file://C:/Users/SKULL\& 1/AppData/Local/Temp/NL730005.pdf. 


\section{INTERNATIONAL ECOLOGICAL POLICY VEKTOR OF AUSTRALIA IN 1979s}

\section{Perga Tetiana}

Candidate of Historical Science, Senior Research Fellow, State Institution "Institute of World History of NAS of Ukraine", Kyiv, Ukraine ORCID: 0000-0002-8725-3451

pergatatiana@gmail.com

The main object of the research is to identify the features of the formative stage of the external vector of Australian environmental policy, which dates back to the 1970s. Methodology of the research is based on an analysis of documents of the Australian Parliament, Department of Foreign Affairs and Trade and the Ministry of Water, Agriculture and Environment. It is found that by the early 1970s, Australia had adopted the first international agreements that formed the basis for the further development of its multilateral environmental cooperation. During this period, various mechanisms and models of multilateral cooperation were developed. The role of United Nations Conference on the Environment held in Stockholm in 1972 in the development of a new level of international environmental cooperation is revealed. It is proven that a number of environmental problems has been has exacerbated in Australia. This led to the country's need for a broad exchange of information with other countries of the world in order to overcome them and to join forces more closely to combat them. By this time in Australia, at both the federal and state levels, government agencies responsible for implementing environmental policies were established. This facilitated the coordination of the internal and external vector of environmental activities. It is concluded that after this conference, in the 1970s, the period of formation of the international vector of Australian environmental policy began. This is justified by the fact that it was based on new principles and background and included new directions. Its peculiarity is demonstrated. It is emphasized on the important role played by the Australian Parliament in the implementation of international agreements.

Key words: Australia; international relations; environmental cooperation; foreign policy; environmental policy; U.N. Conference on the environment of 1972.

(C) Перга Т. Ю., 2021 


\title{
МЕЖДУНАРОДНЫЙ ВЕКТОР ЭКОЛОГИЧЕСКОЙ ПОЛИТИКИ АВСТРАЛИИ: 1970-Е ГОДЫ
}

\author{
Перга Татьяна Юрьевна \\ кандидат исторических наук, старший научный сотрудник \\ ГУ «Институт всемирной истории НАН Украины», \\ 2. Киев, Украина \\ ORCID: 0000-0002-8725-3451 \\ pergatatiana@gmail.com
}

Целью исследования является выявление особенностей этапа становления внешнего вектора экологической политики Австралии, который отнесен к 1970-м годам. Исследование проведено на основе анализа документов Парламента Австралии, Департамента внешних отношений и торговли и Министерства воды, сельского хозяйства и окружающей среды. В результате исследования установлено, что в нач. 1970-х гг. в Австралии был принят ряд первых международных соглашений, которые сформировали основу для дальнейшего развития многостороннего экологического сотрудничества. В этот период были отработаны различные механизмы и модели многостороннего сотрудничества. Раскрыта роль Конференции ООН по Окружающей среде, которая состоялась в Стокгольме в 1972 г., в развитии международного экологического сотрудничества нового уровня. Доказано, что на тот момент в Австралии обострился ряд экологических проблем, что обусловило потребность страны в широком обмене информацией с другими странами мира по их преодолению и более тесного объединения усилий в борьбе с ними. Именно в это время в Австралии на уровне федерации и на уровне штатов были созданы государственные учреждения, ответственные за внедрение экологической политики, что способствовало координации внутреннего и внешнего вектора природоохранной деятельности. Сделан вывод, что именно после этой конференции, в 1970-х гг., начался период становления международного вектора экологической политики Австралии, ведь она основывалась на новых началах и принципах и включила новые направления. Продемонстрирована ее особенность. Отмечена большую роль, которую уделяет Парламент Австралии выполнению международных соглашений.

ключевые слова: Австралия; международные отношения; экологическое сотрудничество; внешняя политика; экологическая политика; Конференция по окружающей среде. 